\title{
Aquatic macroinvertebrates in Madeira Island (Portugal) streams: diversity and distribution
}

\author{
Pedro M. Raposeiro $\ddagger$, Ana Balibrea $\ddagger$, Julie-Camile Riva§, Catarina Johanna Fernandes \\ Rodrigues Ritter $\ddagger$, Vítor Gonçalves $\$$,I \\ ‡ CIBIO, Research Center in Biodiversity and Genetic Resources, InBIO Associate Laboratory / Faculty of Sciences and \\ Technology, University of the Azores, Ponta Delgada, Portugal \\ $\S$ Département de Biologie, Chimie et Géographie, Groupe de recherche sur les environnements nordiques BORÉAS, \\ Université du Québec à Rimouski, Québec, Canada \\ | Faculty of Sciences and Technology, University of the Azores, Ponta Delgada, Portugal
}

Corresponding author: Pedro M. Raposeiro (pedro.mv.raposeiro@uac.pt)

Academic editor: Daniel Silva

Received: 03 Sep 2021 | Accepted: 03 Dec 2021 | Published: 18 Feb 2022

Citation: Raposeiro PM, Balibrea A, Riva J-C, Ritter CJFR, Gonçalves V (2022) Aquatic macroinvertebrates in Madeira Island (Portugal) streams: diversity and distribution. Biodiversity Data Journal 10: e73909.

https://doi.org/10.3897/BDJ.10.e73909

\section{Abstract \\ Background}

The Madeira Island (Portugal; $32^{\circ} 24^{\prime}-33^{\circ} 07^{\prime} \mathrm{N}, 16^{\circ} 16-17^{\circ} 16^{\prime} \mathrm{W} ; 796 \mathrm{~km}^{2}$ ) is an oceanic island located in the North Atlantic, about $980 \mathrm{~km}$ south of Portugal and about $700 \mathrm{~km}$ west of the African coast. The presence of freshwater invertebrates in oceanic islands has always raised questions concerning dispersal, colonisation and evolution. Therefore, the freshwater fauna of Madeira Island has attracted the interest of many researchers in the past, the first publications going back to the nineteenth century. Initial studies were mainly taxonomic, resulting in a checklist of the Madeira freshwater macroinvertebrates with 240 taxa. As typical from oceanic islands, freshwater invertebrates are characterised by low diversity, with some taxonomic groups absent. Although freshwater Madeiran macroinvertebrates are a well-studied group, geographical information of diversity distribution is still scarce. Therefore, more studies are needed, especially georeferenced data of diversity and distribution of macroinvertebrate assemblages, to provide valuable 
information for improving knowledge and the development of typologically appropriate monitoring and conservation programmes and restoration strategies for local stakeholders.

\section{New information}

The results of the present study revealed 713 occurrences in 40 sampling points in Madeira Island streams. The occurrence data showed 70 different aquatic taxa belonging to 21 orders and 53 families. Amongst our occurrence data, 15 endemic taxa $(22.1 \%)$ from Madeira Archipelago were found. In addition, different families of Collembola and different taxa of Copepoda (Onychiuridae, Poduridae, Isotomidae, Entomobryidae, Sminthuridae) comprised new records for the Madeira streams. Therefore, further taxonomic and ecological studies on freshwater invertebrates from Madeira Island should be done with a particular focus on these lesser-known groups. Thus, our data increase the geographical data distribution of freshwater macroinvertebrates and their diversity in Madeira Island. This database is an update of geographical information of diversity distribution of Madeira freshwater macroinvertebrates known groups. This information is essential for a better understanding of community composition, diversity, occurrence or spatial distribution, which will help explore different research questions on different research areas, such as community ecology and biogeography.

\section{Keywords}

aquatic insects, oceanic islands, freshwater systems, geographical distribution

\section{Introduction}

The native stream biodiversity in remote oceanic islands is relatively depleted, compared to mainland counterparts (Covich 2006, Raposeiro et al. 2012, Pereira et al. 2014, Gonçalves et al. 2015). Distance from continental landmasses and the open ocean act as physical barriers limiting species dispersion and colonisation of remote islands (Bilton et al. 2001, Covich 2006). Furthermore, oceanic island freshwaters ecosystems are subject to a complex interaction of multiscale insular biogeographic factors, combined with local conditions on the islands themselves (Bilton et al. 2001, MacArthur and Wilson 2001, Hughes 2005, Borges et al. 2008) that act as biogeographic filters that shape the composition and structure of their communities (Raposeiro et al. 2012). This is the case of Madeiran freshwater macroinvertebrates communities that are considered assemblages with low diversity having some taxonomic groups absent (e.g. Plecoptera and Amphipoda) and many families usually contain few genera with few or even single species (Stauder 1991, Boieiro et al. 2015).

Since the $19^{\text {th }}$ century, freshwater macroinvertebrates communities in Madeira Archipelago have been relatively well researched through scientific expeditions, monitoring programmes and studies on freshwater ecosystems (e.g. Malmqvist 1988, Stauder 1991, 
Hughes 1995, Hughes and Murray 2000, Hughes and Furse 2001, Ferreira and Weihrauch 2005). According to Hughes et al. (1998), 240 macroinvertebrate taxa were recorded for Madeira Island. Freshwater macroinvertebrates communities from Madeira Island present a high degree of endemism (25.5\%) (Hughes 2006, Martín et al. 2017), particularly within the Trichoptera, Coleoptera and Hydracarina groups (Stauder 1991, Baez 1993, Hughes 2003, Vidaña 2020) when compared to continental counterparts. Moreover, over $80 \%$ of the freshwater macroinvertebrates comprises insects, of which $62.5 \%$ are Diptera (Hughes et al. 1998). Endemic taxa usually occupy many biotopes due to the absence of competitors; however, in Madeira Island, most endemisms occur in low order streams at mid-high altitude (500 m a.s.I), located in indigenous Laurel forested areas (Hughes 2006).

As in most regions of the world, freshwater ecosystems of Madeira Islands suffer from environmental degradation due to the increasing anthropogenic pressure (Hughes 2005, Borges et al. 2008, Boieiro et al. 2015). Nonetheless, these are particularly vulnerable given the inherently fragile nature of insular ecosystems, coupled with their exceptional conservation value, considering the high number of endemic species and valuable biota occurring in aquatic and associated habitats (Hughes 2005, Hughes and Malmqvist 2005, Vidaña 2020). Consequently, macroinvertebrate assemblages are used widely as a structural indicator to evaluate ecosystems ecological quality, being an essential tool to understand environment disturbance in these systems and to assess long term temporal and spatial community changes (Metcalfe 1989, Metcalfe 1994, Resh et al. 1995, ZamoraMuñoz and Alba-Tercedor 1996, Czerniawska-Kusza 2005, Hussain 2012, Zeybek et al. 2014).

Despite the extensive knowledge of Madeira freshwater macroinvertebrate communities, little is known about species distribution and its georeference in Madeira Island. Therefore, this work aims to provide insight into the freshwater macroinvertebrate's distribution during a field campaign in Madeira Island streams with georeferenced locations since no similar datasets have been previously published for Madeira.

\section{Project description}

Title: Aquatic macroinvertebrates in Madeira Island (Portugal) streams: diversity and distribution

Personnel: Pedro Raposeiro, Ana Balibrea, Julie-Camile Riva, Catarina Ritter, Vitor Gonçalves

Study area description: Madeira Island is located in the North Atlantic Ocean, $600 \mathrm{~km}$ west of the North Africa coast, between latitudes $32^{\circ}-33^{\circ} \mathrm{N}$ and longitudes $16^{\circ}-17^{\circ} \mathrm{W}$ (Fig. 1). The Island, of volcanic origin, extends for $58 \mathrm{~km}$ along a WNW to ESE axis and has an area of $742 \mathrm{~km}^{2}$ and a maximum altitude of $1861 \mathrm{~m}$ (Pico Ruivo).

Lying in the subtropical region, Madeira's climate is influenced by winds from NE and the Canary Islands current. As a result, the Island has a temperate climate, characterised by mild temperatures ranging from $15.9^{\circ} \mathrm{C}$ in winter up to $22.3^{\circ} \mathrm{C}$ in summer (average annual 
temperature of $18.7^{\circ} \mathrm{C}$ ) with relative humidity between 55 and $75 \%$ and annual rainfall between 500 and 1,000 $\mathrm{mm}$ (Santos et al. 2004).

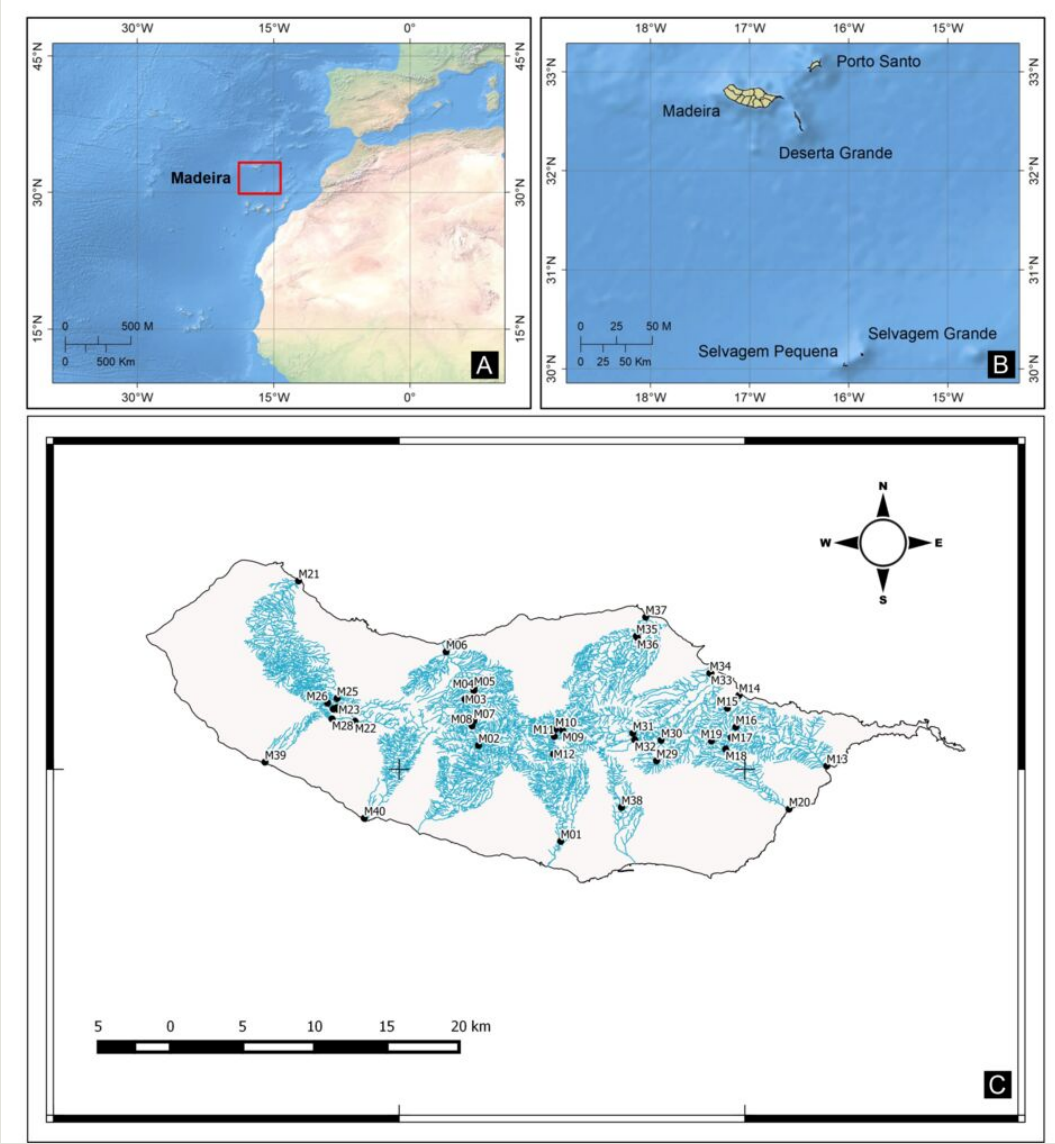

Figure 1. doi

Geographical location of the study stream sites. a Madeira Archipelago in the Atlantic Ocean highlighted by a red square; b Madeira Island in the Madeira Archipelago; c Studied stream sites.

Madeira Island presents a dense hydrographic network, comprising approximately 126 catchments and 200 streams (Marques 1994), ranging from $1^{\text {st }}$ to $6^{\text {th }}$ order. Typical for oceanic islands, streams drop strongly in altitude over very short horizontal distances, often characterised by turbulent, torrential and seasonal flow (Hughes and Malmqvist 2005, Raposeiro et al. 2013). Substrates are predominantly coarse, comprising bedrock, boulders, cobbles and sand. Due to the complex orography of the island, vegetation and land use are distributed along an altitudinal gradient. Madeira's lower altitudes are predominantly occupied by urban and agricultural land uses, while exotic forest plantations are widespread at mid-altitudes. The native forest, Laurissilva, an essential and rare ecosystem and less impacted areas occupy most of the catchments' higher reaches. 
Funding: This work was funded by FCT- Foundation for Science and Technology (PTDC/ CTA-AMB/28511/2017 and DL57/2016/ ICETA/EEC2018/25).

\section{Sampling methods}

Study extent: A total of 40 sites (MAD01-MAD40) distributed by 27 permanent streams (Table 1, Fig. 1) were sampled in the spring of 2015. These sites were selected to cover a wide range of natural variation and human disturbance and ranged from low to high altitudes (Fig. 2).

Table 1.

Sampling codes, altitude, location and name of the stream of the 40 sampling sites on Madeira Island.

\begin{tabular}{|c|c|c|c|c|}
\hline Code & Altitude (m a.s.l.) & Latitude & Longitude & River \\
\hline MAD01 & 85 & 32.66319 & -16.96062 & Ribeira dos socorridos \\
\hline MAD02 & 409 & 32.73395 & -17.02101 & Rib. Brava \\
\hline MAD03 & 450 & 32.76807 & -17.03053 & Rib. da Vargem \\
\hline MAD04 & 325 & 32.77415 & -17.02446 & Rib. de São Vicente \\
\hline MAD05 & 311 & 32.77599 & -17.02434 & Rib. Grande \\
\hline MAD06 & 60 & 32.80288 & -17.04490 & Rib. Grande \\
\hline MAD07 & 903 & 32.75216 & -17.02436 & Rib. Brava \\
\hline MAD08 & 833 & 32.74842 & -17.02574 & Rib. Brava \\
\hline MAD09 & 826 & 32.74522 & -16.95912 & Rib. dos socorridos \\
\hline MAD10 & 725 & 32.74572 & -16.96462 & Rib. da Gomeira \\
\hline MAD11 & 780 & 32.74059 & -16.96515 & Corgo da Ribeira de Aneis \\
\hline MAD12 & 597 & 32.72749 & -16.96529 & Rib. do Cidrão \\
\hline MAD13 & 10 & 32.71876 & -16.76422 & Rib. do Machico \\
\hline MAD14 & 36 & 32.77081 & -16.82892 & Rib. Juncal \\
\hline MAD15 & 187 & 32.76142 & -16.83762 & Rib. Juncal \\
\hline MAD16 & 560 & 32.74741 & -16.83127 & Rib. do Fail \\
\hline MAD17 & 624 & 32.73962 & -16.83465 & Rib. do Machico \\
\hline MAD18 & 791 & 32.73101 & -16.83875 & Rib. Primeira \\
\hline MAD19 & 877 & 32.73715 & -16.84929 & Rib. do Machico \\
\hline MAD20 & 7 & 32.68695 & -16.79204 & Rib. de Santa Cruz \\
\hline
\end{tabular}




\begin{tabular}{|c|c|c|c|c|}
\hline Code & Altitude (m a.s.I.) & Latitude & Longitude & River \\
\hline MAD21 & 81 & 32.85522 & -17.15374 & Rib. da janela \\
\hline MAD22 & 1391 & 32.75164 & -17.11205 & Rib. do Alecrim \\
\hline MAD23 & 1135 & 32.7603 & -17.12407 & Rib. da janela \\
\hline MAD24 & 1089 & 32.76077 & -17.12833 & Rib. da janela \\
\hline MAD25 & 1041 & 32.76834 & -17.12531 & Rib. dos Cedros \\
\hline MAD26 & 899 & 32.76503 & -17.13236 & Rib. da janela \\
\hline MAD27 & 1003 & 32.76191 & -17.12524 & Rib. da janela \\
\hline MAD28 & 1271 & 32.7535 & -17.12897 & Rib. do Alecrim \\
\hline MAD29 & 1182 & 32.72254 & -16.88974 & Rib. Frio \\
\hline MAD30 & 846 & 32.73768 & -16.88639 & Corrego do Arrochete \\
\hline MAD31 & 637 & 32.74293 & -16.9064 & Rib. da Metade \\
\hline MAD32 & 686 & 32.73838 & -16.90569 & Rib. das Lajes \\
\hline MAD33 & 23 & 32.78725 & -16.84971 & Rib. de S. Roque do Faia \\
\hline MAD34 & 42 & 32.78758 & -16.85051 & Rib. Seca \\
\hline MAD35 & 103 & 32.81442 & -16.90435 & Rib. da São Jorge \\
\hline MAD36 & 121 & 32.81342 & -16.90399 & Rib. da Fonte do Louro \\
\hline MAD37 & 21 & 32.82849 & -16.89779 & Rib. de São Jorge \\
\hline MAD38 & 517 & 32.67818 & -16.91823 & Rib. de Santa Luzia \\
\hline MAD39 & 25 & 32.72153 & -17.17844 & Rib. da Fonte do Bugio \\
\hline MAD40 & 22 & 32.68030 & -17.10520 & Rib. da Ponta do Sol \\
\hline
\end{tabular}

Sampling description: Benthic macroinvertebrates were collected following the national sampling protocol (INAG 2008). Benthic samples were composed of six subsamples taken with a kick-net $(0.5 \mathrm{~mm}$ mesh) from the different existing microhabitats along a $50 \mathrm{~m}$ reach, preserved with $96 \%$ ethanol and transported to the laboratory. In the laboratory, samples were rinsed through a sieve of $500 \mu \mathrm{m}$ mesh size and macroinvertebrates were sorted and preserved in $70 \%$ ethanol.

Quality control: Macroinvertebrates were identified under a stereomicroscope (Zeiss Stemi, Deutschland). Identification was made to the lowest possible taxonomic level using identification keys (e.g. Tachet et al. 2000, Oscoz et al. 2011, Kriska 2013). Nonetheless, to facilitate understanding of results, Poduromorpha, Entomobryomorpha and Symphypleona orders were grouped in the same taxonomic group "Collembola"; Isopoda, Podocopida and Copepoda grouped as "Crustacea"; Pulmonata and Sphaeriida as "Mollusca"; Sarcoptiformes and Trombidiformes as "Acari"; Tricladida as "Platyhelminthes"; and Haplotaxida, Lumbriculida, Enchytraeida and Arhynchobdellida as "Annelida". 
Step description: The data has been published as a Darwin Core Archive (DwC-A), which is a standardised format for sharing biodiversity data as a set of one or more data tables. The core data table contains 713 occurrences with 70 records (Raposeiro et al. 2021).
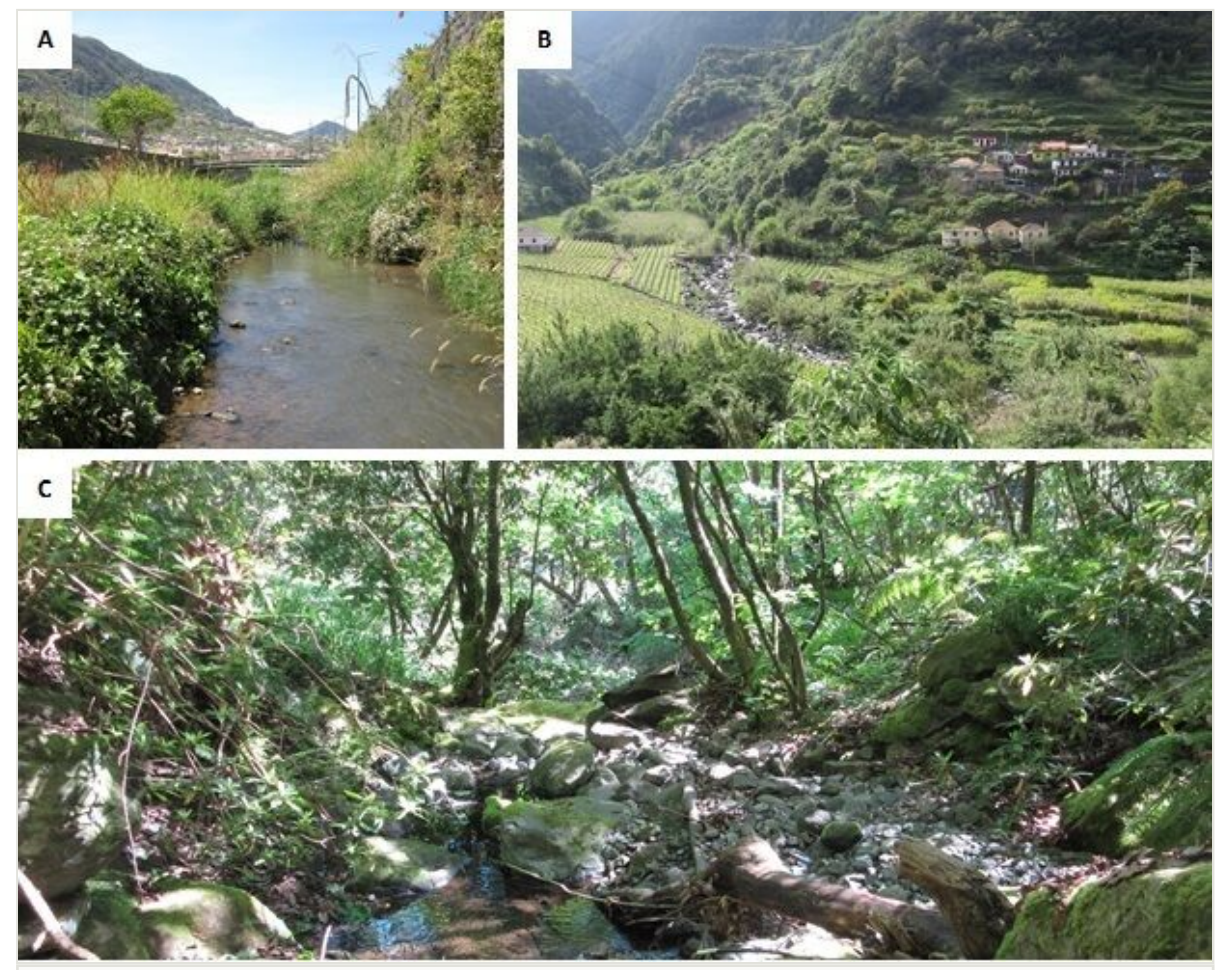

Figure 2. doi

Sampling sites representing A lower reaches (MAD13, Ribeira do Machico); B middle reaches (MAD35, Ribeira de São Jorge) and C upper reaches (MAD30, Córrego do Arrochete).

\section{Geographic coverage}

Description: Madeira Island, Madeira Archipelago, Macaronesia, Portugal.

Coordinates: 32.602 and 32.885 Latitude; -17.287 and -16.639 Longitude.

\section{Taxonomic coverage}

Taxa included:

\begin{tabular}{|l|l|}
\hline Rank & Scientific Name \\
\hline kingdom & Animalia \\
\hline
\end{tabular}




\section{Temporal coverage}

Notes: $2015-04-28$ through 2015-05-02

\section{Usage licence}

Usage licence: Open Data Commons Attribution License

IP rights notes: This work is licensed under a Creative Commons Attribution (CC-BY) 4.0 License.

\section{Data resources}

Data package title: Macroinvertebrates distribution in Madeira Island streams (Portugal)

Resource link: https://www.gbif.org/dataset/bdfe1656-7b5a-4ee5-b334-72b2af17fd9d

\section{Alternative identifiers: http://ipt.gbif.pt/ipt/resource?r=macroinvmad}

\section{Number of data sets: 1}

Data set name: Raposeiro P, Balibrea A, Riva J, Ritter C, Gonçalves V (2021). Macroinvertebrates distribution in Madeira Island streams (Portugal). Version 1.6. Universidade dos Açores. Occurrence dataset https://doi.org/10.15468/48axjg accessed via GBIF.org on 2021-08-25.

Data format: Darwin Core

Data format version: 1.6

Description: This paper presents data from freshwater macroinvertebrate surveys developed in Madeira Island in 2015. The dataset has been published as a Darwin Core Archive (DwC-A), a standardised format for sharing biodiversity data as a set of one or more data tables. The core data table contains 40 events (eventID), 713 occurrences (occurrencelD) with 70 taxa (taxonID). The number of records in the data table is illustrated in the IPT link. This IPT archives the data and, thus, serves as the data repository. The data and resource metadata are available for download in the downloads section.

\begin{tabular}{|l|l|}
\hline Column label & Column description \\
\hline id & Identifier of the occurrence, unique for the dataset. \\
\hline locality & Name of the locality where the event occurred. \\
\hline continent & Continent of the sampling site. \\
\hline country & Country of the sampling site. \\
\hline
\end{tabular}




\begin{tabular}{|c|c|}
\hline islandGroup & Island group of the sampling site. \\
\hline island & Island from the Island Group of the sampling site. \\
\hline municipality & Name of the municipality where the event occurred. \\
\hline waterBody & Water body of the sampling site. \\
\hline eventID & Identifier of the event, unique for the dataset. \\
\hline occurrencelD & Identifier of the record, coded as a global unique identifier. \\
\hline type & The nature of the resource. \\
\hline basisOfRecord & The specific nature of the data record. \\
\hline eventDate & Time interval when the event occurred. \\
\hline scientificName & The name with authorship applied on the first identification of the specimen. \\
\hline taxonID & $\begin{array}{l}\text { The identifier for the set of taxon information (data associated with the Taxon } \\
\text { class). Specific identifier to the dataset. }\end{array}$ \\
\hline Kingdom & Kingdom name. \\
\hline Phylum & Phylum name. \\
\hline Class & Class name. \\
\hline Subclass & Subclass name. \\
\hline Order & Order name. \\
\hline Family & Family name. \\
\hline SubFamily & Subfamily name. \\
\hline Tribe & Tribe name. \\
\hline Genus & Genus name. \\
\hline specificEpithet & The name of the first or species epithet of the scientificName. \\
\hline scientificNameAuthorship & The authorship information for the scientificName. \\
\hline namePublishedlnYear & The publication year of the scientificName. \\
\hline taxonRank & The taxonomic rank of the most specific name in the scientificName. \\
\hline decimalLatitude & The geographic latitude of the sampling site \\
\hline decimalLongitude & The geographic longitude of the sampling site. \\
\hline geodeticDatum & The spatial reference system upon which the geographic coordinates are based. \\
\hline countryCode & Code of the country where the event occurred. \\
\hline coordinateUncertaintyInMetres & $\begin{array}{l}\text { The indicator for the accuracy of the coordinate location in metres, described as } \\
\text { the radius of a circle around the stated point location. }\end{array}$ \\
\hline
\end{tabular}




\section{Additional information}

\section{Data analysis}

The multivariate analyses were performed in PRIMER v.7.0 (including the PERMANOVA plug-in) (Clarke and Gorley 2015). A resemblance matrix was formed using a Bray-Curtis distance (Clarke and Gorley 2015). Cluster analysis was used to identify macroinvertebrates assemblages and a SIMPROF test (test for the significant sign of assembly amongst samples with no pre-defined grouping) was applied to detect significant assemblages. The null hypothesis of no internal group assembly in the full set of samples was rejected when the significance level ( $p$-value) was $<0.01$. Principle Coordinates Ordination (PCO), using BrayCurtis similarity, was used to visualise the structure of macroinvertebrate assemblages.

\section{Results}

The results of the present study revealed 713 occurrences in 40 sampling points in Madeira streams. The occurrence data showed 70 different aquatic taxa belonging to 21 orders and 53 families (Table 2).

Table 2.

Class, order, family and subordinate taxa collected at 40 sampling sites in Madeira Island streams in spring of 2015.

\begin{tabular}{|c|c|c|c|}
\hline Class & Order & Family & Taxa \\
\hline \multirow[t]{14}{*}{ Insecta } & Ephemeroptera & Baetidae & Baetis spp. \\
\hline & \multirow[t]{13}{*}{ Diptera } & Simuliidae & Simulium spp. \\
\hline & & \multirow[t]{5}{*}{ Chironomidae } & Orthocladiinae \\
\hline & & & Tanypodinae \\
\hline & & & Tanytarsini \\
\hline & & & Rheotanytarsus spp. \\
\hline & & & Chironomini \\
\hline & & Thaumaleidae & Thaumalea spp. \\
\hline & & Dixidae & Dixa tetrica Peus, 1934 \\
\hline & & Empididae & Kowarzia spp. \\
\hline & & Tipulidae & Tipulidae \\
\hline & & \multirow[t]{2}{*}{ Ceratopogonidae } & Ceratopogoninae \\
\hline & & & Forcipomyia madeira Clastrier, 1991 \\
\hline & & Limoniidae & Limoniidae \\
\hline
\end{tabular}




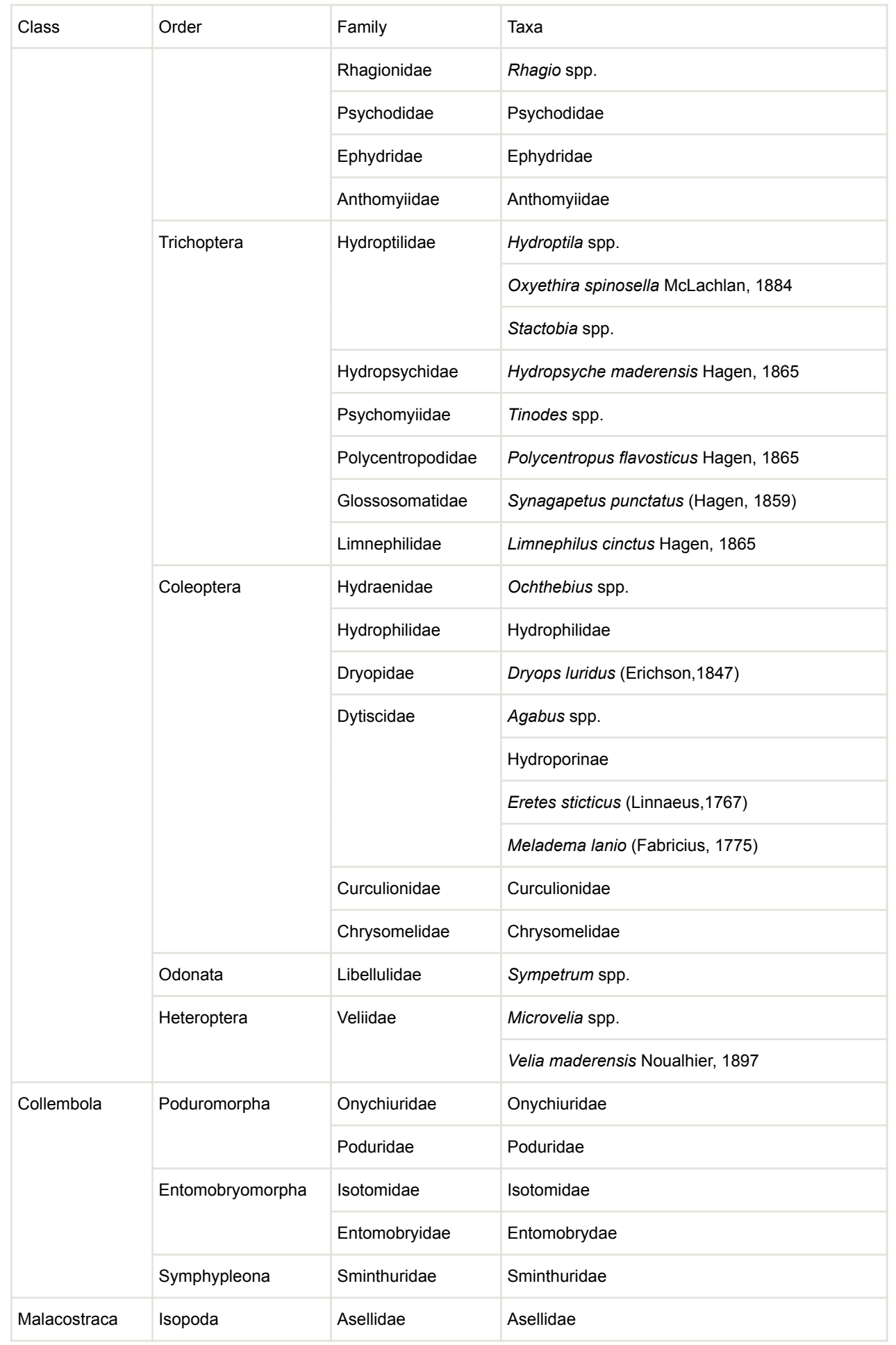




\begin{tabular}{|c|c|c|c|}
\hline Class & Order & Family & Taxa \\
\hline Ostracoda & Podocopida & Cyprididae & Cyprididae \\
\hline Copepoda & Copepoda & & Copepoda \\
\hline \multirow[t]{7}{*}{ Gastropoda } & \multirow[t]{7}{*}{ Pulmonata } & Physidae & Physella acuta (Draparnaud, 1805) \\
\hline & & \multirow[t]{2}{*}{ Lymnaeidae } & Galba truncatula (O.F.Müller, 1774) \\
\hline & & & Radix balthica (Linnaeus, 1758) \\
\hline & & \multirow[t]{4}{*}{ Planorbidae } & Gyraulus spp. \\
\hline & & & Planorbarius corneus corneus (Linnaeus, 1758) \\
\hline & & & Planorbis moquini Requien, 1848 \\
\hline & & & Ancylus aduncus A.A.Gould, 1847 \\
\hline Bivalvia & Sphaeriida & Sphaeriidae & Pisidium spp. \\
\hline \multirow[t]{9}{*}{ Arachnida } & \multirow[t]{2}{*}{ Sarcoptiformes } & Hydrozetidae & Hydrozetes sp. \\
\hline & & Malaconothridae & Trimalaconothrus sp. \\
\hline & \multirow[t]{7}{*}{ Trombidiformes } & Torrenticolidae & Torrenticola spp. \\
\hline & & Lebertiidae & Lebertia spp. \\
\hline & & Hygrobatidae & Atractides spp. \\
\hline & & Sperchontidae & Sperchon brevirostris Koenike, 1895 \\
\hline & & Arrenuridae & Arrenurus autochthonus (Lundblad, 1942) \\
\hline & & Trombidiformes & Trombidiformes \\
\hline & & Unionicolidae & Neumania atlantida (Lundblad, 1941) \\
\hline Rhabditophora & Tricladida & Dugesiidae & Dugesia gonocephala Girard, 1851 \\
\hline \multirow[t]{6}{*}{ Clitellata } & Lumbriculida & Lumbriculidae & Lumbriculus variegatus (O.F.Müller, 1774) \\
\hline & Enchytraeida & Enchytraeidae & Fridericia bulbosa (Rosa, 1887) \\
\hline & \multirow[t]{3}{*}{ Haplotaxida } & Lumbricidae & Lumbricidae \\
\hline & & Tubificidae & Tubifex tubifex (O.F.Müller, 1774) \\
\hline & & Naididae & Naididae \\
\hline & Arhynchobdellida & Erpobdellidae & Dina lineata (O.F.Müller, 1773) \\
\hline
\end{tabular}

The number and percentage composition of families and taxa under different orders are shown in Table 3. The order Diptera showed the most occurrences (36.5\%) in Madeira streams, followed by Trichoptera (14.7\%) and Acari (14.3\%). The orders containing more families were Diptera (12 families) and Acari (8). Diptera, Coleoptera, Acari, Trichoptera and Mollusca were the more diverse aquatic macroinvertebrates orders $(17,9,9,8$ and 8 taxa, respectively). 
Table 3.

Percentage of total occurrences, number and contribution percentage of families and taxa in the different taxonomic groups.

\begin{tabular}{|l|l|l|l|l|l|}
\hline Taxonomic groups & \% total occurrences & no. of family & \% of family & no. of taxa & \% of taxa \\
\hline Ephemeroptera & 5.6 & 1 & 1.9 & 1 & 1.4 \\
\hline Diptera & 36.5 & 12 & 22.6 & 17 & 24.3 \\
\hline Trichoptera & 14.7 & 6 & 11.3 & 8 & 11.4 \\
\hline Coleoptera & 2.5 & 6 & 11.3 & 9 & 12.9 \\
\hline Odonata & 0.7 & 1 & 1.9 & 1 & 1.4 \\
\hline Heteroptera & 0.7 & 1 & 1.9 & 2 & 2.9 \\
\hline Collembola & 2.7 & 5 & 9.4 & 5 & 7.1 \\
\hline Crustacea & 5.0 & 3 & 5.7 & 3 & 4.3 \\
\hline Mollusca & 7.7 & 3 & 5.7 & 8 & 11.4 \\
\hline Acari & 14.3 & 8 & 1 & 1.9 & 12.9 \\
\hline Platyhelminthes & 1.8 & 6.7 & 11.3 & 6 & 1.4 \\
\hline Annelida & 7.7 & & & 8.6 \\
\hline
\end{tabular}

Chironomidae presented the highest frequency amongst aquatic macroinvertebrate families, with five taxa (Orthocladiinae, Tanypodinae, Tanytarsini, Chironomini and Rheotanytarsus spp.) contributing with $17.4 \%$ of the total occurrences, $7.7 \%$ from the subfamily Chironominae, $5.6 \%$ from Orthocladiinae and $4.1 \%$ from Tanypodinae. Hydroptilidae family, in the Coleoptera order, was also frequent in Madeira streams contributing with $6.7 \%$ of the occurrences and containing three taxa (Hydroptila spp., Oxyethira spinosella McLachlan, 1884 and Stactobia spp.). Baetidae family, in the Ephemeroptera order, although only represented by Baetis spp., was also common (40 sites, contributing with $5.6 \%$ ), followed by Simuliidae family (40 sites; $5.6 \%$ ), belonging to Diptera order and represented by Simulium spp. and family Naididae (38 sites; $5.3 \%$ ) from the Annelida group. Dytiscidae and Planorbidae were the families that showed higher diversity, with 4 (Agabus spp., Hydroporinae, Eretes sticticus (Linnaeus,1767) and Meladema lanio (Fabricius, 1775)) and three taxa (Gyraulus spp., Planorbarius corneus corneus (Linnaeus, 1758) and Ancylus aduncus A.A. Gould, 1847) representing each family, respectively.

Moreover, other taxa also considered most ubiquitous in Madeira streams are Orthocladiinae, Tanytarsini, Hydroptila spp. and Naididae presented in 40, 38, 36 and 34 sites. The mean number of taxa per sample was 18.8 \pm 0.9 SE taxa. Sampling sites MAD03, MAD06, MAD16, MAD18, MAD19, MAD30, MAD34, MAD36 and MAD37, showed the highest number of taxa with $24,23,31,25,31,27,22,24$ and 27, respectively. In contrast, MAD01 (10 taxa), MAD05 (8 taxa), MAD06 (7 taxa) and MAD11 (10 taxa) presented the lowest number of taxa. 
A total of 23 invertebrate taxa that occurred at only one to three sampling sites were considered rare. These include Diptera taxa as Forcipomyia madeira Clastrier, 1991, Rhagio spp., Psychodidae and Anthomyiidae families. Moreover, three Coleoptera species (Dryops luridus (Erichson,1847), Eretes sticticus, Meladema lanio) and three families and one subfamily of Coleoptera, Hydrophilidae, Curculionidae, Chrysomelidae and Hydroporinae were identified. In addition, a Heteroptera species Velia maderensis Noualhier, 1897; two Collembola families, such as Isotomidae and Entomobrydae; the Mollusca species Radix balthica (Linnaeus, 1758), Planorbis moquini Requien, 1848 and Pisidium spp.; Arrenurus autochthonus (Lundblad, 1942) and Neumania atlantida (Lundblad, 1941), species belonging to Acari group; and three Annelida species Lumbriculus variegatus (O.F. Müller, 1774), Fridericia bulbosa (Rosa, 1887) and Tubifex tubifex (O.F. Müller, 1774) were also considered as rare taxa amongst the sampled streams.

Amongst our occurrence data, 15 taxa $(22.1 \%)$ were described previously as endemic invertebrates of the Madeira Archipelago. The genus Baetis is represented on the Island by two endemic species, Baetis enigmaticus Gattolliat \& Sartori, 2008 and Baetis maderensis (Hagen, 1865) (not distinguished in our survey) and it seems to be the most frequent endemism (present in all 40 sampling sites). Kowarzia and Thaumalea genera (Diptera) are also endemic taxa that are present in 24 and 15 studied sites, respectively. Trichoptera was the order with the higher number of endemisms, including the more common Tinodes spp. and Polycentropus flavosticus Hagen, 1865, present in 16 and 14 sites, respectively and the less frequent Stactobia spp. (7 sites), Synagapetus punctatus (Hagen, 1859) (4 sites) and Limnephilus cinctus Hagen, 1865 (4 sites). Acari species, belonging to Torrenticola, Lebertia and Atractides genera, are also freshwater endemisms very common in Madeira streams, present in 22, 16 and 19 sites, respectively. Other endemic species that occasionally appeared (from 9 to 4 sampling sites) were Ancylus aduncus and Agabus spp. Moreover, the endemic Heteroptera species, Velia maderensis and Coleoptera species Meladema lanio, were considered rare endemisms because they were only present in one sampling site (MAD19 both species). Some of the taxa mentioned above, found in Madeira streams, are shown in Fig. 3.

The cluster analysis indicated a split into two significantly different assemblages (Fig. 4, SIMPROF Global test $\pi=1.67, p<0.1$ ). SIMPER analysis revealed a dissimilarity of $51.6 \%$ between these two assemblages. The taxa that contributed most to the dissimilarity were Physella acuta (4.8\%), Dugesia gonocephala (3.9\%), Kowarzia spp. (3.8\%), Dixa tetrica (3.5\%), Cyprididae (3.3\%) and Tinodes spp. (3.2\%). The PCO analyses further supported the differences in assemblage composition between the two assemblages. The first two PCO axes explained $26.5 \%$ of total variation (Fig. 5). The first axis of the ordination ( $16.0 \%$ of total variation) was positively correlated to the altitudinal gradient and it separates the two different assemblages revealed by the SIMPROF. Therefore, the two macroinvertebrate assemblages are: 1) Lower altitude assemblages - most of the lower reaches located below $400 \mathrm{~m}$ a.s.I. These assemblages are characterised by the higher occurrence of non-endemic taxa, such as Physella acuta (85\%), Cyprididae (85\%), Dugesia gonocephala (77\%), Hydrozetes sp. (69\%), Galba truncatula (54\%) and Tipulidae 
(54\%) as revealed by the negative PCO1 scores. 2) Higher altitude assemblages comprise the majority of lower reaches located above $400 \mathrm{~m}$ a.s.l. These assemblages are characterised by the higher occurrence of endemic taxa (endemic for Madeira and endemic for Macaronesia), such as Kowarzia spp. (78\%), Dixa tetrica (74\%), Thaumalea spp. $(56 \%)$ and Hydropsyche maderensis $(56 \%$,$) , as revealed by the positive PCO1$ scores.

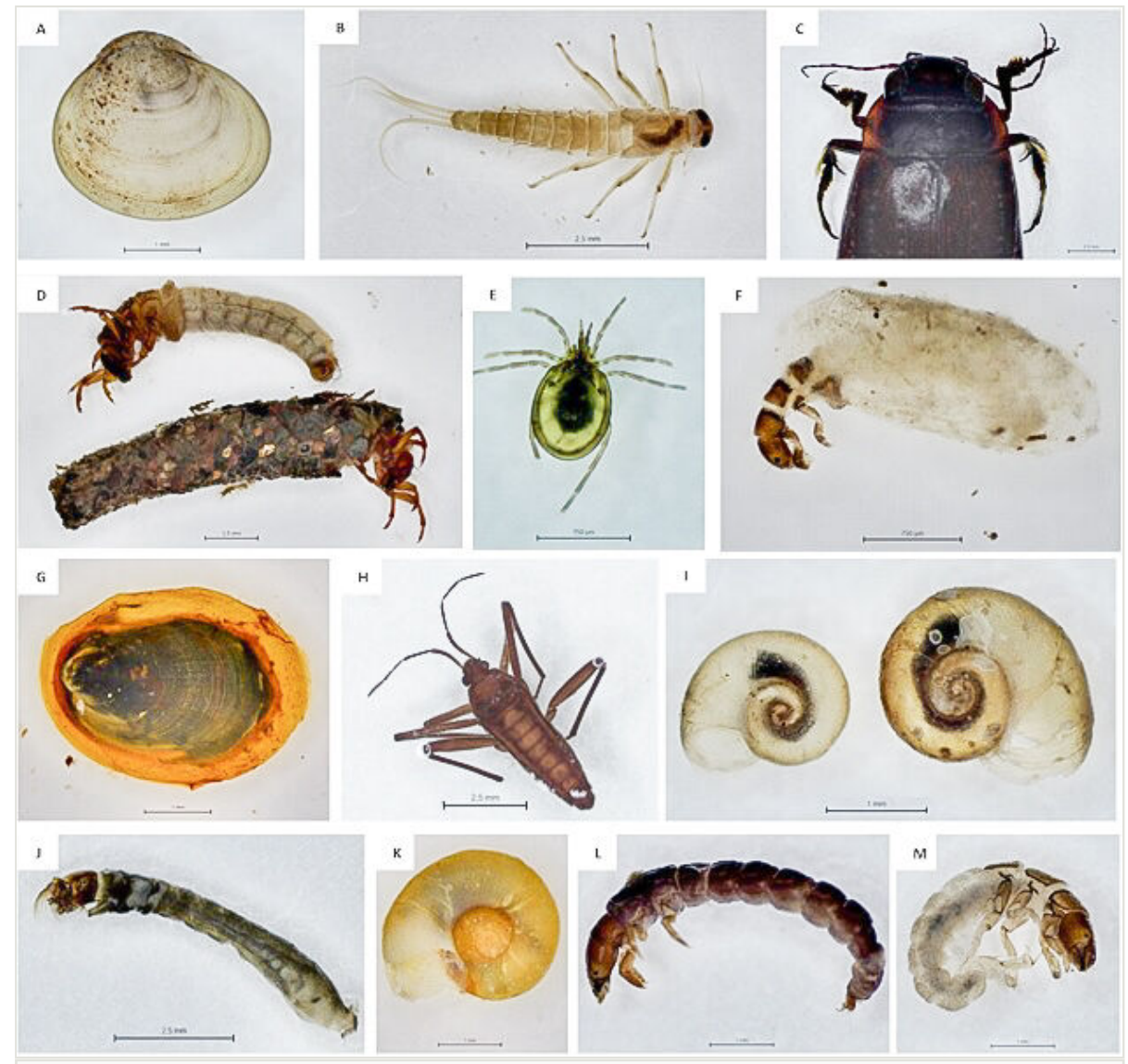

Figure 3. doi

Some macroinvertebrates found from Madeira streams: A Pisidium sp.; B Baetis sp.; C Meladema lanio; D Limnephilus cinctus; E Torrenticola sp.; F Hydroptila sp.; G Ancylus aduncus; H Velia maderensis; I Planorbis moquini; J Simulium sp.; K Gyraulus sp.; L Tinodes sp.; $\mathbf{M}$ Hydropsyche maderensis.

\section{Discussion}

This study revealed how simple Madeira macroinvertebrate stream communities are compared to typologically similar continental rivers (e.g. mountain rivers), but richer when compared to other remote oceanic islands. We found 53 families of macroinvertebrates in 
Madeira Island streams, while Martins et al. (2020) reported 94 families of macroinvertebrates in a mainland Portuguese stream and Leunda et al. (2009) identified 74 families from a Spanish stream. Compared to even more remote oceanic islands, like the Azores Archipelago (32 families in Raposeiro et al. (2013), Ferreira et al. (2016)), Madeira Island stream communities were more diverse. This paucity of freshwater macroinvertebrates has been reported for other oceanic islands (e.g. Brasher et al. 2004, Raposeiro et al. 2012, Raposeiro et al. 2013, Balibrea et al. 2020a). However, these differences cannot draw conclusions regarding low diversity since sampling efforts used were different and have time-restricted to one season. Moreover, non-lotic systems, such as temporary or artificial ponds, were not sampled which could also contribute to the low number of aquatic macroinvertebrate taxa found (70) from the total freshwater species known to the Archipelago (240 taxa in Hughes et al. (1998)).

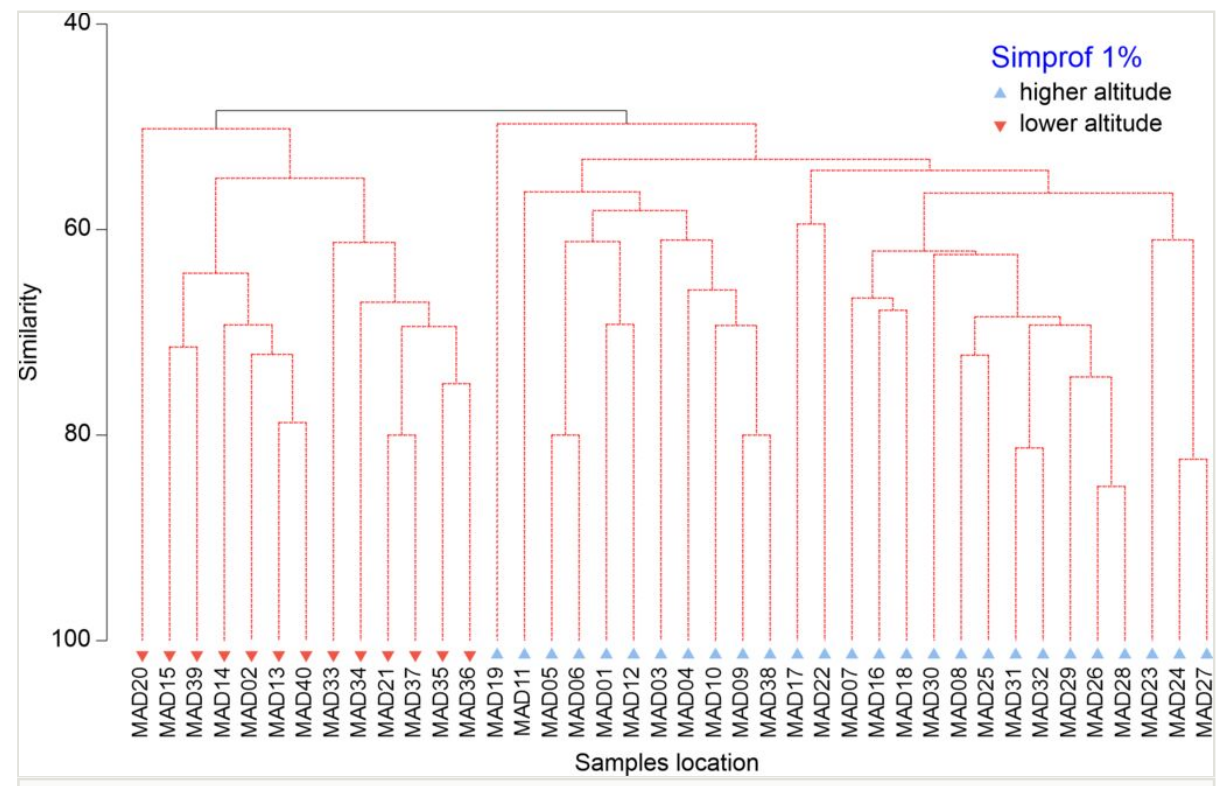

Figure 4. doi

Cluster analyses of macroinvertebrate data according to their similarity. Similarity profile (SIMPROF) permutation tests were used to test for significant differences in the hierarchical cluster structure (i.e. the red dotted lines) at the $99 \%$ level.

The most frequent macroinvertebrate taxa were from the Diptera order, especially the highly mobile taxa with multivoltine life cycle patterns, such as the Chironomidae (Berg and Hellenthal, 1992; Tokeshi, 1995). The dominance of Diptera was also reported to other oceanic islands, such as the Azores (Raposeiro et al. 2013), the Canaries (Malmqvist et al. 1993, Malmqvist et al. 1995) and Hawaii (Brasher et al. 2004). The second-largest group of stream invertebrates in Madeira Island is Acari, followed by Coleoptera and Trichoptera, which is in agreement with the total recorded freshwater aquatic fauna to the Island (Kelly et al. 2002,Borges et al. 2008). 
The most well-distributed taxa on the current survey were Baetis spp., Simulium spp. and Hydroptila spp. The distribution of genus Baetis (represented by two endemic species) does not seem to be affected by local environmental factors because it was found in all 40 sampling sites. Hughes (2006) found the same pattern on some endemic trichopteran species that have extended beyond their typical ecological habitat due to the lack of competitors and trophic shift tolerance, thus spreading widely into many diverse stream habitats. This may also explain the high number of occurrences of Simulium spp. and Hydroptila spp. found in all studied sites.

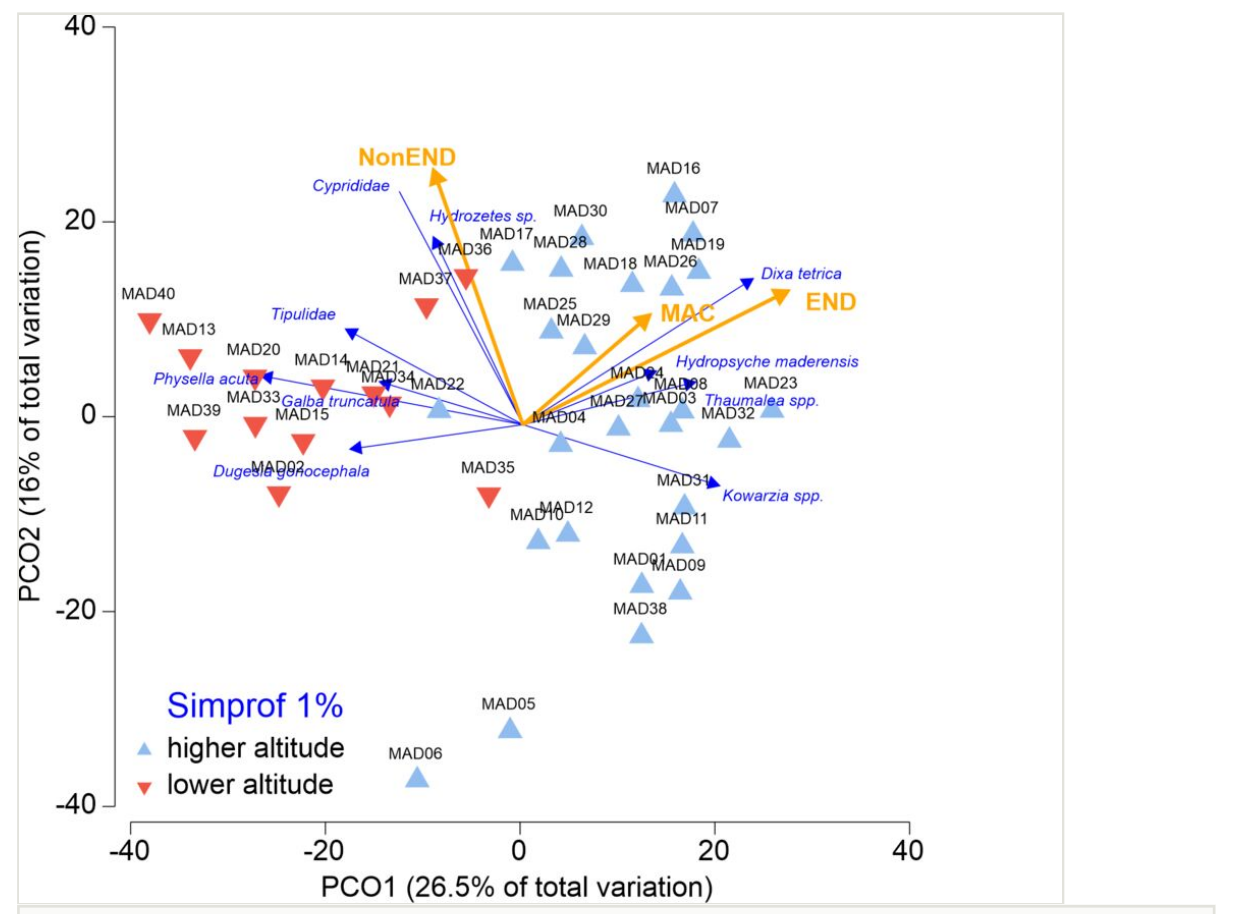

Figure 5. doi

Principal Coordinate Ordination (PCO) of the first and second axes. (Non-END - non-endemic taxa; END - Endemic taxa; MAC - Endemic taxa for Macaronesia)

Despite the large distribution of several endemic taxa, changes in the taxa occurence from the upper to lower reaches were observed jointly with a decline in endemic taxa occurrence (Fig. 5). Environmental differences between the upper and lower reaches are very distinct. Upper reaches are mainly located on the native forest with relatively undisturbed catchments (Raposeiro et al. 2020, Ritter et al. 2020). In contrast, human disturbances are much more significant in the lower reaches, where many stream banks have been changed considerably. According to several authors (França and Almeida 2003, Hughes 2005, Hughes 2006), there are significant changes from acidic, oligotrophic with low conductivity in the upper reaches to basic, meso-eutrophic with an increase in conductivity to lower reaches. The longitudinal physicochemical gradients are consistent with findings of several studies that illustrate change along the river continuum in 
association with altitude, land use and energy input (Vannote et al. 1980, Harding et al. 1999, Raposeiro et al. 2013, Gonçalves et al. 2015) and, thus, assemblages of macroinvertebrates are tightly associated with these water parameters (Godoy et al. 2017, Godoy et al. 2018). Significant differences in taxonomic richness amongst altitudinal and different land-use were also documented in previous studies performed on other oceanic islands (Raposeiro et al. 2013) and in continental temperate (Stone and Wallace 1998) and tropical systems (Encalada et al. 2010).

Even though Madeira aquatic fauna is considered well-studied due to studies done since the middle of the $19^{\text {th }}$ century on different groups of invertebrate inhabiting island freshwaters (e.g. Wollaston 1854, Hagen 1865, Eaton 1873, McLachlan 1882, Puton 1889 , Reuter 1890, Hughes et al. 1998), little is known for some taxonomic groups. For example, different families of Collembola (Onychiuridae, Poduridae, Isotomidae, Entomobryidae, Sminthuridae) were recorded for the first time in Madeira freshwaters in the present study, as well as different taxa of Copepoda. Therefore, further taxonomic and ecological studies on freshwater invertebrates from Madeira Island should be done with a particular focus on these lesser-known groups.

\section{Final remarks}

Due to the complexity and a wide range of freshwater habitats in the Madeira Island and large scale-effects from the Islands' isolation and biogeographical filters (Smith et al. 2003, Covich 2006, Covich 2009), further studies done on freshwater communities may reveal new endemic species that may inhabit remote and inaccessible areas of the Island. Like all insular systems, Madeira freshwater systems are potentially highly vulnerable to invasive species due to the low levels of diversity (and therefore competitors) and the relative availability of ecological niches. The increasing connectivity of this Island with the mainland may also promote the transport accidentally or deliberately of new species (Gonçalves et al. 2008, Chainho et al. 2015, Lamelas-López et al. 2017, Balibrea et al. 2020b, Lenzner et al. 2020, Costa et al. 2021). Moreover, the effect of human activity related to freshwater resources, habitat degradation and water quality deterioration may dramatically change the invertebrate fauna of lotic ecosystems in this Archipelago (Hughes 2005, Leena et al. 2013, Leena et al. 2015). Thus, appropriate monitoring and conservation programmes should be undertaken on these delicate freshwater systems to understand communities' distribution and dynamics better. Such knowledge implies the active collaboration between politicians, scientists and the local population.

\section{Acknowledgements}

This work was funded by FCT - Foundation for Science and Technology, the European Union, QREN, FEDER, COMPETE programmes, by funding the CIBIO/InBIO (project UID/ $\mathrm{BIA} / 50027 / 2020$ and POCl-01-0145-FEDER-006821) and PMR (DL57/2016/ICETA/ EEC2018/25). We thank the reviewers for their comments and suggestions that helped improve the manuscript. 


\section{Author contributions}

Vítor Gonçalves and Pedro Miguel Raposeiro conceived the study and carried out the sampling campaign. Identification was done by Julie Camile, Ana Balibrea and Pedro Raposeiro. Pedro Miguel Raposeiro, Ana Balibrea and Catarina Ritter wrote the paper with inputs from all authors. All authors agree with the final version of the manuscript.

\section{References}

- $\quad$ Baez M (1993) Origins and affinities of the fauna of Madeira. Boletim do Museu Municipal do Funchal 2: 9-40.

- $\quad$ Balibrea A, Gonçalves V, Raposeiro PM (2020a) Larval description of Limnephilus atlanticus Nybom 1948, morphological comparison with Limnephilus affinis Curtis 1834, (Trichoptera: Limnephilidae) and additional notes on their ecology in Azores Islands. Zootaxa 4852 (3): 372-382. https://doi.org/10.11646/zootaxa.4852.3.8

- Balibrea A, Ferreira V, Balibrea C, Gonçalves V, Raposeiro PM (2020b) Contribution of macroinvertebrate shredders and aquatic hyphomycetes to litter decomposition in remote insular streams. Hydrobiologia 847 (10): 2337-2355. https://doi.org/10.1007/ s10750-020-04259-1

- $\quad$ Bilton DT, Freeland JR, Okamura B (2001) Dispersal in freshwater invertebrates. Annual Review of Ecology and Systematics 32: 159-181. https://doi.org/10.1146/ annurev.ecolsys.32.081501.114016

- $\quad$ Boieiro M, Aguiar AF, Rego C, Borges PAV, Serrano ARM (2015) The biodiversity of terrestrial arthropods in Madeira and Selvagens archipelagos. Revista IDE@-SEA 6: 1-20.

- Borges P, Abreu C, Aguiar A, Carvalho P, Jardim R, Melo I, Oliveira P, Sérgio C, Serrano A, Vieira $P$ (2008) Listagem dos fungos, flora e fauna terrestres dos arquipélagos da Madeira e Selvagens: A list of the terrestrial fungi, flora and fauna of Madeira and Selvagens archipelagos. Direcção Regional do Ambiente da Madeira and Universidade dos Açores, Funchal and Angra do Heroísmo, 440 pp.

[ISBN 9789899579002]

- $\quad$ Brasher AMD, Wolff RH, Luton CD (2004) Associations among land use, habitat characteristics, and invertebrate community structure in nine streams on the Island of Oahu, Hawaii. U.S. Geological Survey Water-Resources Investigations, Report 03-4256, Honolulu, Hawaii.

- Chainho P, Fernandes A, Amorim A, Ávila S, Canning-Clode J, Castro J, Costa A, Costa J, Cruz T, Gollasch S, Grazziotin-Soares C, Melo R, Micael J, Parente M, Semedo J, Silva T, Sobral D, Sousa M, Torres P, Veloso V, Costa M (2015) Non-indigenous species in Portuguese coastal areas, coastal lagoons, estuaries and islands. Estuarine, Coastal and Shelf Science 167: 199-211. https://doi.org/10.1016/j.ecss.2015.06.019

- $\quad$ Clarke KR, Gorley RN (2015) Getting started with PRIMER v7. PRIMER-E: Plymouth Marine Laboratory, Plymouth, 20pp.

- Costa AC, Balibrea A, Raposeiro PM, Santos S, Souto M, Gonçalves V (2021) Nonindigenous and invasive freshwater species on the Atlantic Islands of the Azores 
Archipelago. Frontiers in Ecology and Evolution 9 (631214). https://doi.org/10.3389/ fevo.2021.631214

- $\quad$ Covich A (2006) Dispersal limited tropical insular streams. Polish Journal of Ecology 54 (4): 523-547.

- $\quad$ Covich A (2009) Freshwater ecology. In: Gillespie RG, Clague DA (Eds) Encyclopedia of islands. University of California Press, Berkeley, 343-347 pp.

[ISBN 978-0-520-25649-1].

- Czerniawska-Kusza I (2005) Comparing modified biological monitoring working party score system and several biological indices based on macroinvertebrates for waterquality assessment. Limnologica 35 (3): 169-176. https://doi.org/10.1016/j.limno. 2005.05.003

- Eaton AE (1873) On the Hydroptilidae, a family of Trichoptera. Transactions of the Entomological Society of London 2: 125-150.

- Encalada A, Calles J, Ferreira VV, Canhoto C, Graça MS (2010) Riparian land use and the relationship between the benthos and litter decomposition in tropical montane streams. Freshwater Biology 55 (8): 1719-1733. https://doi.org/10.1111/j.

1365-2427.2010.02406.x

- $\quad$ Ferreira S, Weihrauch F (2005) Annotated bibliography of odonatological literature from continental Portugal, Madeira, and the Azores (Odonata). Libellula 24: 109-128.

- $\quad$ Ferreira V, Raposeiro P, Pereira A, Cruz A, Costa A, Graça MS, Gonçalves V (2016) Leaf litter decomposition in remote oceanic island streams is driven by microbes and depends on litter quality and environmental conditions. Freshwater Biology 61 (5): 783-799. https://doi.org/10.1111/fwb.12749

- França J, Almeida A (2003) Plano regional de água da Madeira. Síntese do diagnóstico e dos objetivos. Simpósio de Hidráulica e Recursos Hídricos dos Países de Língua Oficial Portuguesa. Cidade da Praia, República de Cabo Verde, de 10 a 12 de Novembro 751-760.

- $\quad$ Godoy BS, Queiroz LL, Lodi S, Oliveira LG (2017) Environment and spatial influences on aquatic insect communities in cerrado streams: The relative importance of conductivity, altitude, and conservation areas. Neotropical Entomology 46 (2): 151-158. https://doi.org/10.1007/s13744-016-0452-4

- $\quad$ Godoy BS, Camargos LM, Lodi S (2018) When phylogeny and ecology meet: Modeling the occurrence of Trichoptera with environmental and phylogenetic data. Ecology and Evolution 8 (11): 5313-5322. https://doi.org/10.1002/ECE3.4031

- Gonçalves V, Raposeiro P, Costa AC (2008) Benthic diatoms and macroinvertebrates in the assessment of the ecological status of Azorean streams. Limnetica 27 (2): 317-328. https://doi.org/10.23818/limn.27.25

- $\quad$ Gonçalves V, Marques HS, Raposeiro PM (2015) Diatom assemblages and their associated environmental drivers in isolated oceanic island streams (Azores archipelago as case study). Hydrobiologia 751 (1): 89-103. https://doi.org/10.1007/ s10750-015-2174-8

- Hagen H (1865) The Neuroptera of Madeira. Phyrganidae. Entomologist's Monthly Magazine 2: 75-81.

- Harding JS, Young R, Hayes JW, Shearer K, Stark JD (1999) Changes in agricultural intensity and river health along a river continuum. Freshwater Biology 42 (2): 345-357. https://doi.org/10.1046/j.1365-2427.1999.444470.x 
- Hughes SJ (1995) A biological monitoring system for the freshwater resources of Madeira; some preliminary results. Boletim do Museu Municipal do Funchal 4: 325-351.

- Hughes SJ, Furse M, Blackburn J, Langthorn P (1998) A checklist of Madeiran freshwater macroinvertebrates. Boletim do Museu Municipal do Funchal 50 (284): 5-41.

- Hughes SJ, Murray DA (2000) New record of Chironomidae to Madeira and comments on possible new forms. In Late 20th Century Research on Chironomidae: an anthology from the 13th International Symposium on Chironomidae. $8 \mathrm{pp}$.

- Hughes SJ, Furse MT (2001) Development of a biotic score for the assessment of the ecological quality of the rivers and streams of Madeira. Arquipelago Life and Marine Sciences Supplement (2 Part B)19-32.

- Hughes SJ (2003) A study of the freshwater macroinvertebrate fauna of Madeira and their application in a regional ecological monitoring system. PhD thesis, King's College Division of Life Sciences, University of London, UK.

- Hughes SJ (2005) Application of the Water Framework Directive to Macaronesian freshwater systems. Biology and Environment 105 (3): 185-193. https://doi.org/10.3318/ BIOE.2005.105.3.185

- Hughes SJ, Malmqvist B (2005) Atlantic Island freshwater ecosystems: Challenges and considerations following the EU Water Framework Directive. Hydrobiologia 544 (1):

289-297. https://doi.org/10.1007/s10750-005-1695-y

- Hughes SJ (2006) Temporal and spatial distribution patterns of larval Trichoptera in Madeiran streams. Hydrobiologia 553 (1): 27-41. https://doi.org/10.1007/ s10750-005-0627-1

- Hussain Q (2012) Macroinvertebrates in streams: A review of some ecological factors. International Journal of Fisheries and Aquaculture 4 (7): 114-123. https://doi.org/ 10.5897/ijfa11.045

- INAG IP (2008) Manual para a avaliação biológica da qualidade da água em sistemas fluviais segundo a Directiva Quadro da Água: protocolo de amostragem e análise para os macroinvertebrados bentónicos. Ministério do Ambiente, do Ordenamento do Território e do desenvolvimento Regional. Instituto da Água IP, 164.

- Kelly L, Rundle S, Bilton D (2002) Genetic population structure and dispersal in Atlantic Island caddisflies. Freshwater Biology 47 (9): 1642-1650. https://doi.org/10.1046/j. 1365-2427.2002.00912.x

- Kriska G (2013) Freshwater invertebrates in Central Europe: A field guide. SpringerVerlag Wien, Austria, 411 pp. [ISBN 978-3-7091-1547-3] https://doi.org/ 10.1007/978-3-7091-1547-3

- $\quad$ Lamelas-López L, Raposeiro PM, Borges PV, Florencio M (2017) Annotated checklist of aquatic beetles (Coleoptera) and true bugs (Heteroptera) in the Azores Islands: new records and corrections of colonization status. Zootaxa 4353 (1). https://doi.org/ 10.11646/zootaxa.4353.1.7

- $\quad$ Leena L, Bergamini A, Figueira R, Sim-Sim M (2013) Riparian bryophyte communities on Madeira: patterns and determinants of species richness and composition. Journal of Bryology 32 (1): 32-45. https://doi.org/10.1179/037366810X12578498135751

- Leena L, Bergamini A, Sim-Sim M (2015) Which environmental factors best explain variation of species richness and composition of stream bryophytes? A case study from mountainous streams in Madeira Island. Aquatic Botany 123: 37-46. https://doi.org/ 10.1016/j.aquabot.2015.01.010 
- Lenzner B, Latombe G, Capinha C, Bellard C, Courchamp F, Diagne C, Dullinger S, Golivets M, Irl SH, Kühn I, Leung B, Liu C, Moser D, Roura-Pascual N, Seebens H, Turbelin A, Weigelt $P$, EssI $F$ (2020) What will the future bring for biological invasions on islands? An expert-based assessment. Frontiers in Ecology and Evolution 8: 280. https://doi.org/10.3389/fevo.2020.00280

- Leunda P, Oscoz J, Miranda R, Ariño A (2009) Longitudinal and seasonal variation of the benthic macroinvertebrate community and biotic indices in an undisturbed Pyrenean river. Ecological Indicators 9 (1): 52-63. https://doi.org/10.1016/j.ecolind.2008.01.009

- MacArthur RH, Wilson EO (2001) The Theory of Island Biogeography. Princeton University Press, Princeton. [ISBN 9781400881376] https://doi.org/10.1515/ 9781400881376

- Malmqvist B (1988) Downstream drift in Madeiran Levadas: Tests of hypotheses relating to the influence of predators on the drift of insects. Aquatic Insects 10 (3): 141-152. https://doi.org/10.1080/01650428809361323

- Malmqvist B, Nilsson AN, Baez M, Armitage PD, Blackburn JCN-2 (1993) Stream macroinvertebrate communities in the island of Tenerife. Archiv für Hydrobiologie 128 (2): 209-235. https://doi.org/10.1127/archiv-hydrobiol/128/1993/209

- Malmqvist B, Nilsson A, Baez M (1995) Tenerife's freshwater macroinvertebrates: Status and threats (Canary Islands, Spain). Aquatic Conservation: Marine and Freshwater Ecosystems 5 (1): 1-24. https://doi.org/10.1002/aqc.3270050103

- Marques Z (1994) Avaliação dos recursos hídricos superficiais da llha da Madeira (Fase1). Laboratório Nacional de Engenharia Civil. Núcleo de Hidrologia e Hidráulica Fluvial. Relatório 30/94. 146 pp.

- Martín L, Martínez J, Aguín-Pombo D, González M (2017) A new endemic Synagapetus species (Trichoptera: Glossosomatidae) from Madeira Island (Portugal). Zootaxa 4286 (2): 296-300. https://doi.org/10.11646/zootaxa.4286.2.13

- Martins FMS, Porto M, Feio MJ, Egeter B (2020) Modelling technical and biological biases in macroinvertebrate community assessment from bulk preservative using multiple metabarcoding markers. Molecular Ecology 2021 (30): 3221-3238.

https://doi.org/10.1111/mec. 15620

- McLachlan R (1882) The Neuroptera of Madeira and the Canary Islands. Zoological Journal of the Linnean Society 16: 149-183. https://doi.org/10.1111/j.10963642.1882.tb02279.x

- Metcalfe J (1989) Biological water quality assessment of running waters based on macroinvertebrate communities: History and present status in Europe. Environmental Pollution 60 (1-2): 101-139. https://doi.org/10.1016/0269-7491(89)90223-6

- Metcalfe J (1994) Biological water-quality assessment of rivers: Use of macroinvertebrate communities. In: Calow P, Petts GE (Eds) The Rivers Handbook. Blackwell Science Ltd, Oxford, 26 pp. https://doi.org/10.1002/9781444313871.ch8

- Oscoz J, Galicia D, Miranda R (2011) Identification guide of freshwater macroinvertebrates of Spain. Springer Netherlands, Dordrecht, 411 pp. [ISBN 978-94-007-1553-0] https://doi.org/10.1007/978-94-007-1554-7

- Pereira CL, Raposeiro PM, Costa AC, Bao R, Giralt S, Gonçalves V (2014) Biogeography and lake morphometry drive diatom and chironomid assemblages' composition in lacustrine surface sediments of oceanic islands. Hydrobiologia 730 (1): 93-112. https://doi.org/10.1007/s10750-014-1824-6 
- Puton $\mathrm{A}$ (1889) Excursions hèmipterologique à Tenerife et à Madère par Maurice Noualhier. Revue Entomologique 8: 293-310.

- Raposeiro P, Faustino H, Ferreira V, Gonçalves V (2020) Aquatic hyphomycetes from streams on Madeira Island (Portugal). Biodiversity Data Journal 8 https://doi.org/ 10.3897/BDJ.8.e53690

- $\quad$ Raposeiro P, Balibrea A, Riva J, Ritter C, Gonçalves V (2021) Macroinvertebrates distribution in Madeira Island streams (Portugal). Version 1.6. Universidade dos Açores. Occurrence dataset. via GBIF.org https://doi.org/10.15468/48axjg

- Raposeiro PM, Cruz AM, Hughes SJ, Costa AC (2012) Azorean freshwater invertebrates: Status, threats and biogeographic notes. Limnetica 31 (1): 13-22. https://doi.org/10.23818/limn.31.02

- $\quad$ Raposeiro PM, Hughes SJ, Costa AC (2013) Environmental drivers - spatial and temporal variation of macroinvertebrate communities in island streams: the case of the Azores Archipelago. Fundamental and Applied Limnology / Archiv für Hydrobiologie 182 (4): 337-350. https://doi.org/10.1127/1863-9135/2013/0384

- $\quad$ Resh V, Norris R, Barbour M (1995) Design and implementation of rapid assessment approaches for water resource monitoring using benthic macroinvertebrates. Australian Journal of Ecology 20 (1): 108-121. https://doi.org/10.1111/j.1442-9993.1995.tb00525.x

- $\quad$ Reuter OM (1890) Notes sur quelques Hémiptères de Madère. Revue Entomologique 9: 260-262.

- $\quad$ Ritter C, Raposeiro PM, Gonçalves V (2020) Diatom diversity and distribution in Madeira Island streams (Portugal). Biodiversity Data Journal 8 (176).

- Santos FD, Valente MA, Miranda PM, Barbosa Aguiar AC, Valente MA, Miranda PMA, Aguiar A, Azevedo EB, Tomé AR (2004) Climate change scenarios in the Azores and Madeira Islands. World Resource Review 16 (4): 473-91.

- $\quad$ Smith GC, Covich AP, Brasher AMD (2003) An ecological perspective on the biodiversity of tropical island streams. BioScience 53:1048-1051. https://doi.org/ 10.1641/0006-3568(2003)053[1048:AEPOTB]2.0.CO;2

- $\quad$ Stauder A (1991) Water fauna of a Madeiran stream with notes on the zoogeography of the Macaronesian Islands. Boletim do Museu Municipal do Funchal 43 (235): 243- 299.

- $\quad$ Stone MK, Wallace JB (1998) Long-term recovery of a mountain stream from clear-cut logging: the effects of forest succession on benthic invertebrate community structure. Freshwater Biology 39 (1): 151-169. https://doi.org/10.1046/j.1365-2427.1998.00272.x

- Tachet H,P, Richoux P, Bournaud M, Usseglio-Polatera P (2000) Invertébrés d'eau douce: Systématique, biologie, écologie. CNRS Ed, Paris, 608 pp. [ISBN 2271069459]

- Vannote RL, Minshall GW, Cummins KW, Sedell JR, Cushing CE (1980) The river continuum concept. Canadian Journal of Fisheries and Aquatic Sciences 37 (1): 130-137. https://doi.org/10.1139/f80-017

- Vidaña AE (2020) Macroinvertebrates assemblages in the Canary Islands and Madeira. MSc thesis in Terrestrial Biodiversity and Conservation on Islands, University of La Laguna, Spain.

- Wollaston TV (1854) Insecta Maderensia. London,634 pp.

- Zamora-Muñoz C, Alba-Tercedor J (1996) Bioassessment of organically polluted Spanish rivers, using a biotic index and multivariate methods. Journal of the North American Benthological Society 15 (3): 332-352. https://doi.org/10.2307/1467281

- Zeybek M, Kalyoncu H, Karakaş B, Özgül S (2014) The use of BMWP and ASPT indices for evaluation of water quality according to macroinvertebrates in Değirmendere 
Stream (Isparta, Turkey). Turkish Journal of Zoology 38 (5): 603-613. https://doi.org/ 10.3906/zoo-1310-9 